\title{
ASSESSMENT OF ECOLOGICAL WATER QUALITY ALONG A RURAL TO URBAN LAND USE GRADIENT USING BENTHIC MACROINVERTEBRATE- BASED INDEXES
}

\author{
AVALIAÇÃO DA QUALIDADE ECOLÓGICA DA ÁGUA AO LONGO DE UM \\ GRADIENTE RURAL-URBANO UTILIZANDO ÍNDICES BASEADOS EM \\ MACROINVERTEBRADOS BENTÔNICOS.
}

\begin{abstract}
Aline Leles NASCIMENTO ${ }^{1}$; Fernanda ALVES-MARTINS ${ }^{2}$; Giuliano Buzá JACOBUCCI ${ }^{3}$
1. Graduate Program in Ecology and Natural Resources Conservation, Federal University of Uberlândia - UFU, Uberlândia, MG, Brazil; 2. Federal University of Goiás - UFG, Goiânia, GO, Brazil. fernandaalvesmartins@ yahoo.com.br; 3. Federal University of Uberlândia - UFU, Uberlândia, MG Brazil.
\end{abstract}

\begin{abstract}
Agricultural practices such as livestock grazing and tilling can result in soil erosion and runoff of fine sediments, nutrients (e.g. nitrogen, phosphorus, potassium) and pesticides, leading to degradation of aquatic environments. Urbanization is also responsible for a variety of impacts on fluvial ecosystems, including pollution by heavy metals, oil, domestic sewage and garbage. In this study, we evaluate the impact of land use on stream health of the Uberabinha river catchment. Overall, rural streams presented better ecological conditions than urban streams. Both species composition and abundance of benthic communities showed significant differences between rural and urban streams. Urban streams presented a higher dominance of Oligochaeta, Hirudinea and Gastropoda, bioindicators of poor water quality. Rural streams presented significantly greater richness and diversity. Compared to urban streams, rural streams presented a significantly higher number of Ephemeroptera, Plecoptera, Trichoptera, Odonata and Hemiptera taxa. Our analyses also showed congruence (high correlation) among the classical biodiversity metrics (Shannon-Wiener index - H', Pielou's measure of eveness - J) and monitoring parameters (\% Ephemeroptera, Plecoptera and Trichoptera - EPT, Biological Monitoring Work Party - BMWP, bioindicator approach and Rapid Assessment Protocol - RAP, a habitatbased approach). Five from seven rural streams presented good water quality according to both BMWP and RAP and none of the urban streams presented good water quality. Our results show that the urban streams of Uberlândia municipality are poor ecosystems, and require improved management actions by environmental authorities. We also encourage that the riparian forest restoration and management carried out in the upper portion of Uberabinha River catchment to be extended to the urban area of the municipality.
\end{abstract}

KEYWORDS: Aquatic degradation. Species diversity. EPT. BMWP.

\section{INTRODUCTION}

Aquatic ecosystems have been impacted by numerous human activities, derived from both agricultural and urban activities (MANGADZE et al., 2013). Agricultural practices such as livestock grazing and tilling can result in soil erosion and runoff of large amounts of fine sediments, nutrients (e.g. nitrogen, phosphorus) and pesticides, leading to degradation of aquatic environments. Urbanization is also responsible for a variety of impacts including pollution by heavy metals, oil, domestic sewage and garbage (STEPENUCK et al., 2002). Additionally, the increase of catchment imperviousness enhances stormwater runoff and channel erosion, both contributing to river quality degradation (WALSH et al., 2001; MOORE; PALMER, 2005). These alterations in stream quality affect aquatic assemblages (ALLAN et al., 1997) by reducing overall diversity, increasing the number of tolerant organisms and decreasing the number of sensitive organisms, leading to the homogenization of communities (SMITH; LAMP, 2008; HEPP et al., 2010).

The high population density in urban areas typically results in larger modifications to the environment with high concentrations of pollutants (GODRON; FORMAN, 1983). Rural environments, which are sparsely populated, exhibit less built-up areas and lower concentrations of pollution (GODRON; FORMAN, 1983, MCDONNEL et al., 1997). Therefore, it is expected that aquatic ecosystems located in urban areas are more impacted by water pollution than aquatic ecosystems located in rural areas (MCDONNEL et al., 1997). Some studies have demonstrated that urbanization changes benthic macroinvertebrate community composition and abundance (PEDERSEN; PERKINS, 1986). RESH; JACKSON (1993) observed that impacts from human activities particularly affect aquatic insects of the Ephemeroptera, Plecoptera and Trichoptera (EPT) orders, often recognized as bioindicators due to their high sensitivity to organic pollution (e.g. 
DOLÉDEC et al., 2006), whilst other organisms such as Oligochaeta, Mollusca and some Chironomidae genera (Insecta: Diptera) are acknowledged for their tolerance to organic waste (CALLISTO et al., 2001, ROLDÁN-PÉREZ, 2003).

Benthic macroinvertebrates have been widely used in biomonitoring programs (see ALBATERCEDO, 1996, CALLISTO et al., 2000). Some characteristics, such as high abundance in streams, small body size, short life cycle, and a wide range of responses to pollution favor their use in aquatic ecosystem monitoring (ROSENBERG; RESH, 1993, COUCEIRO et al., 2012). Their potential to assess water quality has been widely used through the application of different biomonitoring protocols, based on the premise that pollution tolerance differs among taxonomic groups (RESH et al., 1996). For instance, the Biological Monitoring Working Party (hereafter BMWP), a simple and adaptable index, has been widely implemented worldwide and adapted to regional peculiarities (e.g. ARMITAGE et al., 1983 - United Kingdom; JUNQUEIRA; CAMPOS, 1998 - Brazil; WYŻGA et al., 2013 Poland; GUTIÉRREZ-FONSECA; LORION, 2014 - Costa Rica). In the BMWP, system families are assigned a score between 1 and 10 according to their sensitivity to pollution. The BMWP score is the sum of the values for all families present in the stream sample. The higher the score, the better the ecological condition of the stream (MASON, 2002). The macroinvertebrate sampling facilities, the index calculation and also its direct interpretation of the perturbation status of a particular stream makes BMWP easily manageable (ZAMORA-MUÑOZ et al., 1995).

Another convenient approach consists of habitat-based protocols - a visual inspection of structural habitat features. These are based on the assumption that certain river parameters such as land use, riparian vegetation, bank structure, water color and smell, among others, reflect the environmental quality of the fluvial habitat (i.e. river). In the habitat-based protocol approach, parameters are assigned a score according to stream ecological conditions. The higher the score, the better the stream's conservation status (CALLISTO et al., 2001). Besides the use of different protocols, it is worth noting that classical biological variables such as richness, abundance and evenness also provide relevant information about the status of water quality. Generally, impacted environments show low diversity values with a limited number of resistant species (MELO; HEPP, 2008).

The aim of this study was to compare the impact of rural and urban activities on stream health of the Uberabinha river catchment, using macroinvertebrates as water quality bioindicators. Commencing in 2009, the upper portion of the Uberabinha River catchment has been the subject of ongoing riparian forest restoration and management (rural zone of Uberlândia municipality) through the Buriti Program for Recovery of Riparian Forests, established by Uberlândia's Water and Sewerage Department (ANA, 2015). As a result, we expect that the conservation status of sites in the rural area to be better than those in the urban perimeter of the city. We tested the hypothesis that macroinvertebrate composition and abundance is different between urban and agricultural streams within the study area. We expect that rural streams, which we assumed to be less impacted by human activities, particularly by domestic and industrial discharge, have higher diversity index values (richness, H', J', higher percentage of EPT), lower abundance, lower percentage of Chironomidae and Oligochaeta, higher BMWP scores and also present better habitat conditions.

\section{MATERIAL AND METHODS}

The study was undertaken in the Uberabinha River catchment which is located in the geographical region of Triângulo Mineiro, Minas Gerais, Southeastern Brazil. It integrates the Paraná river catchment, represented by the Mesozoic age lithologies: sandstones of Botucatu Formation, basalts of Serra Geral Formation and rocks of the Bauru Group (NISHIYAMA, 1989). The local climate is tropical and classed as AW, megatermic, under the Köppen climate classification, with summer rains and winter drought (ROSA et al., 1991; GUIMARÃES-SOUTO et al., 2009). The Uberabinha catchment drainage is subject to different land uses. At the upper and lower course, land use is predominantly agricultural (BRANDÃO, 2002). At the middle course, land use is predominantly urban and includes Uberlândia, a city of about 600,000 inhabitants (IBGE, 2010).

We surveyed 12 streams in different regions of the Uberabinha river catchment, grouped according to main land use: five streams were located within the urban area and seven streams located within agricultural landscapes (Figure 1). The selected streams are subject to different levels of perturbation (BRANDÃO, 2002). The upper portion of the Uberabinha catchment comprises the rural streams Beija-Flor (hereafter $\mathrm{BjFl}$ ), Rancharia (Ranch) and Bom-Jardim (BJd). Although surrounded by an agricultural matrix, they have been relatively preserved due to the presence of 
riparian forest and other typical vegetation types (native grass). Cabeceira do Lageado (Laged) is located in a relatively pristine ecological reserve (Reserva do Clube de Caça e Pesca), approximately $10 \mathrm{~km}$ from Uberlândia city. The streams Liso (Liso), Óleo (Oleo), Lagoinha (Lago), Buritizinho (Buri) and Fundo (Fund) are located at the urban perimeter of Uberlândia municipality. These streams are surrounded by built-up areas and subject to various kinds of anthropogenic impacts, primarily due to the loss of vegetation along the stream banks and inflow of domestic sewage and garbage (BORGES et al., 2006; GUIMARÃES-SOUTO et al., 2011). At the lower portion of the Uberabinha catchment are located the rural streams Machados (Mach), Gordura (Gord) and Rio das Pedras (Pedr). These streams are surrounded by agriculture, pasture and riparian forest.

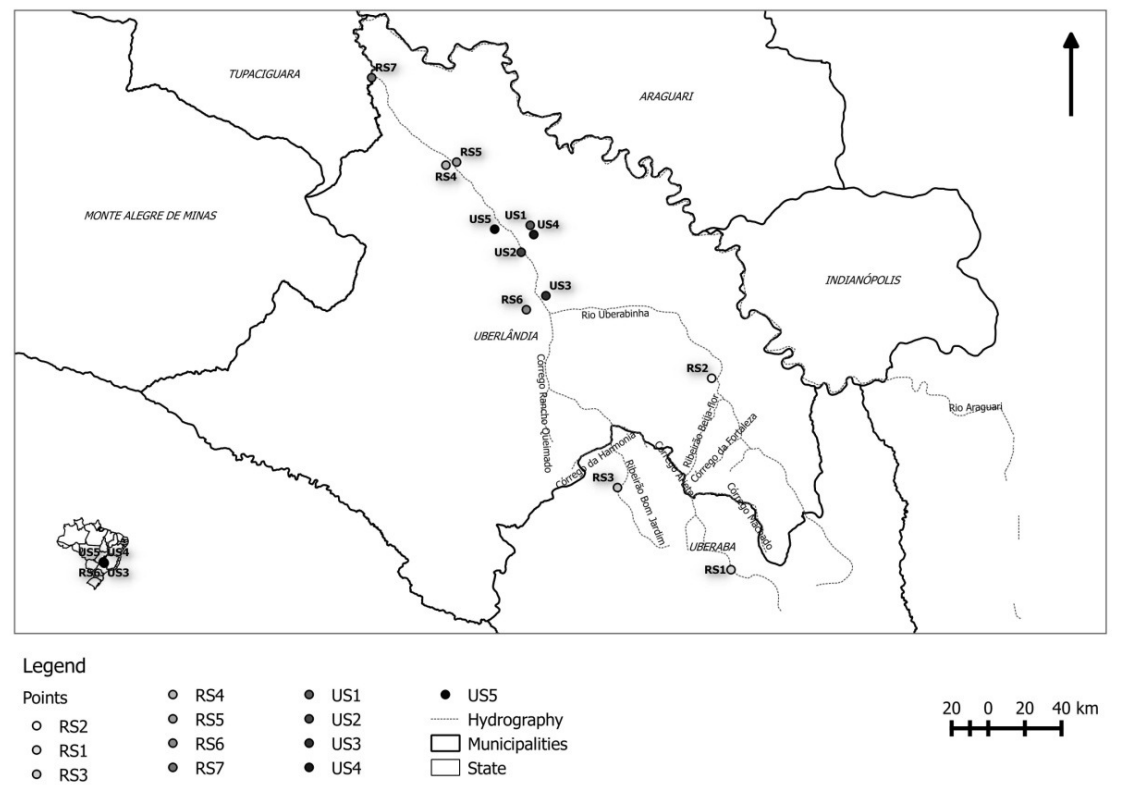

Figure 1. Uberabinha river catchment and the twelve sampling sites. Open circles - Rural Samples (RS); Black circles - Urban Samples (US). RS1 - Beija-Flor stream; RS2 -Rancharia stream; RS3 - Bom Jardim stream; RS4 - Machados stream; RS5 - Gordura stream; RS6 - Cabeceira do Lageado stream; RS7 - Rio das Pedras stream; US1 -Liso stream; US2 - Óleo stream; US3 - Lagoinha stream; US4 - Buritizinho stream; US5 -Fundo stream.

Benthic macroinvertebrate surveys were performed during the dry season (August and September/2010). At each stream, data was collected at the middle course, along a $100 \mathrm{~m}$ section of wadeable, running water. Three points were selected within this section and three substrate sub-samples were randomly collected using a Surber collector of $900 \mathrm{~cm}^{2}$ with $0.25 \mathrm{~mm}$ mesh size. The three sub-samples of each point were pooled as one representative sample (see GUIMARÃES-SOUTO et al., 2011). Sampling was performed by disturbing the Surber delimited sediment area for one minute. Samples were bottled, labeled and fixed in a $10 \%$ formalin solution. At the laboratory, benthic macroinvertebrates were identified to the family level, except for Collembola (Order), Anellida (Subclass), Mollusca (Class) and Nematoda (Phylum). Specific identification keys were used (e.g. MERRIT; CUMMINS, 1984) and when necessary, expertise confirmation was sought. For both the description of macroinvertebrate community structure and biomonitoring purposes, identifying macroinvertebrates to family level has been demonstrated to be as informative as generalevel data (WARWICK, 1988; BOWMAN; BAILEY, 1998; WAITE et al., 2004; JONES, 2008).

For each sampling site, different biodiversity indexes were calculated, including taxa richness, Shannon-Wiener diversity index $\left(\mathrm{H}^{\prime}\right)$ and the percentage of Ephemeroptera, Plecoptera and Trichoptera (EPT), Oligochaeta and Chironomidae (for details see Appendices). In order to compare a bioindicator-based framework to a habitat-based one, a BMWP index was calculated (Biological Monitoring Working Party - ALBA-TERCEDOR 1996), adapted for the Cerrado biome. Water quality classes were determined for different BMWP score 
intervals (very bad: $\leq 16$; bad: 17 - 36; satisfactory: 37 - 63; good: 64 - 85; excellent: $\geq 86$ ) (JUNQUEIRA; CAMPOS, 1998). A stream habitat approach was also used, also known as 'Rapid Assessment Protocol' (hereafter RAP). This protocol is a rapid and qualitative habitat assessment developed to describe overall quality of the physical habitat, and is based on a visual inspection of the site by incorporating several habitat attributes which are assigned numerical scores along a gradient of optimal to poor (EPA, 1987; HANNAFORD et al., 1997). The total score of the attributes results in three habitat classes (impacted: 0 - 40; altered: 41 60; natural: $\geq 61$ ) (CALLISTO et al., 2002).

To test the hypothesis that macroinvertebrate composition and abundance were different among urban and agricultural streams, a Non-Parametric Multivariate Analysis of Variance was performed (PERMANOVA). Presence-absence records were used to assess effects on composition data. Abundance data was calculated as the average number of individuals at the three substrate sampling units and further log transformed. The rationale for transforming abundance data was to better estimate the contribution of rare and common families (ANDERSON, 2001). A Principal Component Analysis was also performed (PCA) to inspect collinearity between the diversity parameters and to examine associations between the diversity parameters and the surveyed streams. Analyses were carried out in the "vegan" package of the statistical environment $R$ ( $R$ DEVELOPMENT CORE TEAM, 2008).

\section{RESULTS}

A total of 191,947 individuals, belonging to 50 taxa were sampled: Insecta (43), Gastropoda (3), Annelida (2), Collembola (1) and Plathyhelminthes (1). The most abundant families in both rural and urban streams were Chironomidae and Simuliidae. Ephemeroptera and Plecoptera were prevalent in rural streams while Gastropods were prevalent in urban streams (for further details see Appendices). Both the composition and abundance of benthic communities showed significant differences between rural and urban streams (PERMANOVA, F-ratio $=3.491, \mathrm{p}=0.044, \mathrm{df}=10$, and F-ratio $=3.332$, $\mathrm{p}=0.049, \quad \mathrm{df}=10, \quad$ respectively for species composition and abundance).

According to BMWP biological scores, almost all rural streams presented "excellent" water quality, except the Machados stream, which presented "good" water quality, and Gordura, which presented "satisfactory" water quality. Urban streams differed widely according to the BMWP. Fundo stream presented "good" water quality; Liso, Óleo and Lagoinha streams were classified as "satisfactory", while Buritizinho was classified as "bad" according to the biological score (Figure 2).

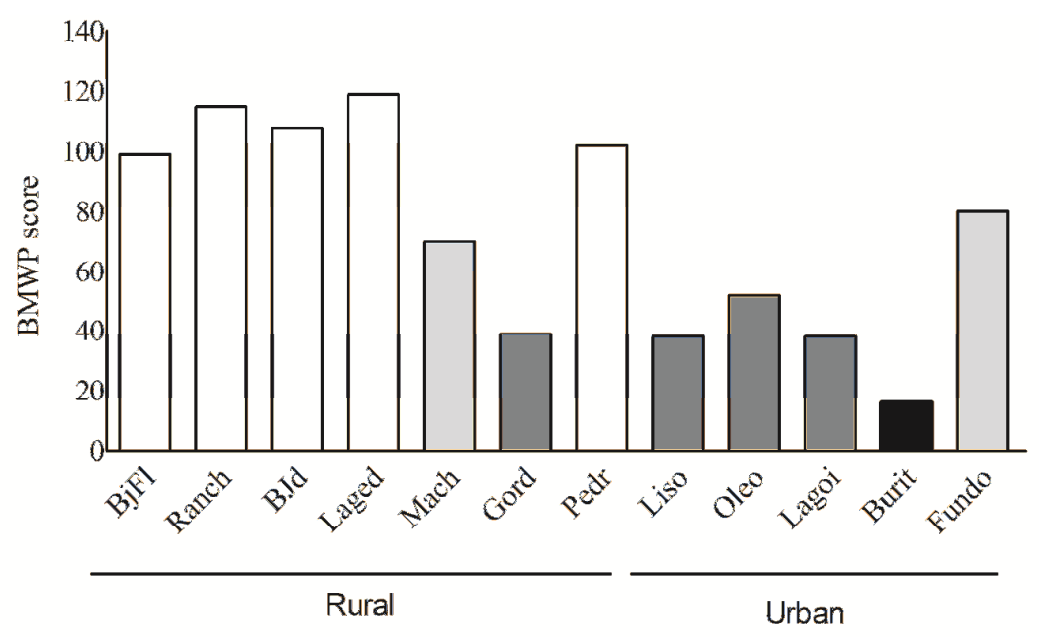

Figure 2. Assessment of environmental quality according to BMWP (bioindicator-based approach). Different colors represent different water quality according to BMWP criteria: White - excellent; Light-grey good; Dark-grey - satisfactory; black - bad.

The application of RAP showed that in general, rural streams presented "natural" conditions, except for Machados, which was classified as "altered" and Gordura, which was classified as "impacted". Urban streams presented worse habitat conditions than rural ones. Liso, Lagoinha and Fundo streams were classified as 
"altered". Óleo and Buritizinho were classified as "impacted" (Figure 3).

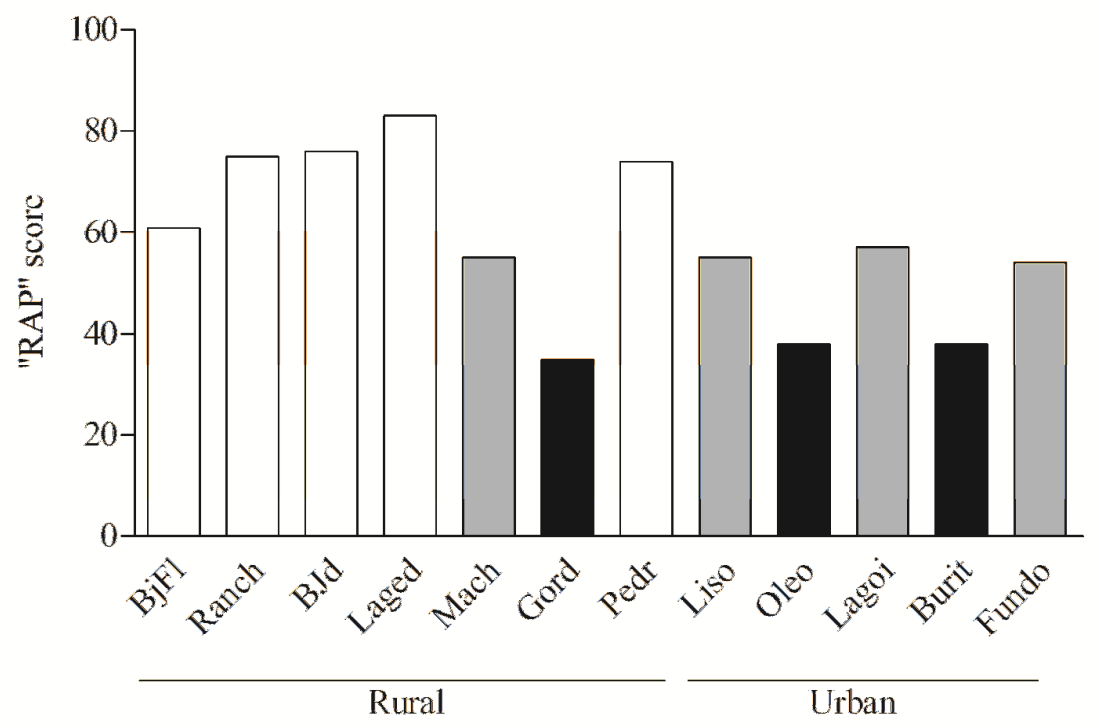

Figure 3. Assessment of environmental quality according to Rapid Assessment Protocol (habitat-based approach). Different colors represent different water quality, according to RAP criteria: White natural streams; Grey - altered streams; Black - impacted streams.

The Principal Component Analysis (PCA) showed high correlation among the traditional diversity indices $\mathrm{H}^{\prime}$ and $\mathrm{J}$, the sensitive groups - \% EPT - and the two biomonitoring approaches (BMWP and RAP) in axes construction (Table 2). In the first axis, the most important metrics were Oligochaeta percentage, with negative loading, and Shannon-Wiener diversity (H'), with positive loading. In the second axis, \% Chironomidae was the most important variable, followed by J' (Table 1). Generally, rural streams were related to $H^{\prime}, J^{\prime}$, EPT, BMWP, Chironomidae and RAP, while urban streams were related to \% Oligochaeta and abundance (Figure. 3). The first two axes explained 60.69 and $19.94 \%$ of the total variation respectively.

Table 1. Component loadings for the first and second axis of the Principal Component Analysis. The largest component loadings in each axis are in bold.

\begin{tabular}{lll}
\hline Variables & PC1 & PC2 \\
\hline \hline H' & $\mathbf{0 . 3 8 9}$ & 0.338 \\
J' & 0.339 & $\mathbf{0 . 4 5 3}$ \\
Abundance & -0.353 & 0.027 \\
BMWP & 0.389 & -0.309 \\
\% Chironomidae & 0.192 & $\mathbf{- 0 . 5 5 6}$ \\
\% Oligochaeta & $\mathbf{- 0 . 4 2 9}$ & 0.082 \\
\% EPT & 0.352 & 0.320 \\
RAP & 0.321 & -0.407 \\
\hline
\end{tabular}



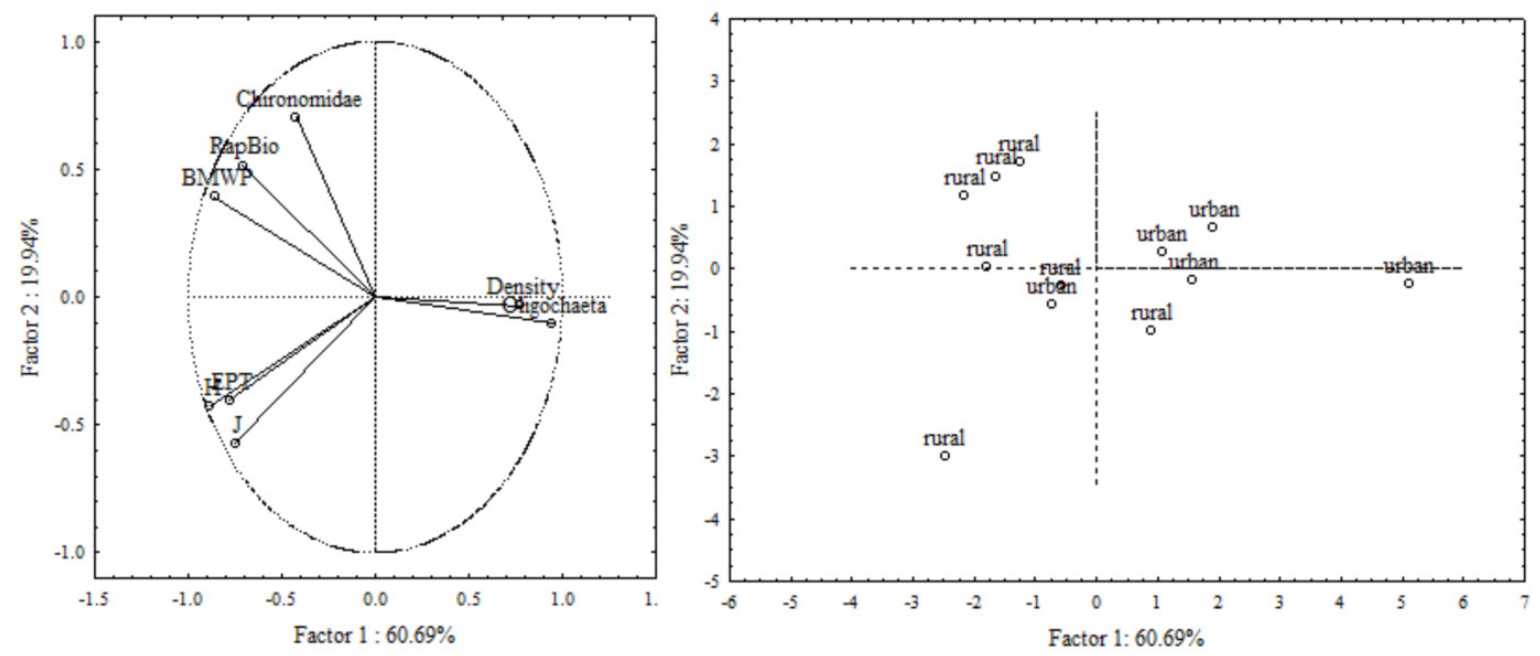

Figure 3. Ordination diagram of the biodiversity metrics (left) and surveyed streams (right) by Principal Component Analysis (PCA).

\section{DISCUSSION}

Overall, our results showed that both community composition and abundance of macroinvertebrates were significantly different between rural and urban streams in the Uberabinha river catchment. In addition, rural streams showed higher BMWP and RAP scores, higher percentage of EPT and Chironomidae, higher richness, eveness and Shannon-Wiener diversity (richness, J', H').

Streams affected by both urban and agricultural activities undergo changes which influence the quality and availability of resources, as well as their ecological integrity, resulting in significant modifications to the structure and composition of the benthic community (BUSS et al., 2002; HEPP; SANTOS, 2009; MILESI et al., 2009). Urbanization may be more detrimental to aquatic ecosystems than agricultural practices as the high population density in urban areas typically results in high concentrations of pollution (STEPENUCK et al., 2002) from multiple sources, such as stormwater drainage, domestic and industrial sources (WALSH et al., 2001; MOORE; PALMER, 2005). Moreover, the absence of riparian vegetation, more frequent in the urban streams of the Uberabinha river catchment (BORGES et al., 2006; GUIMARÃES-SOUTO et al., 2011), increases vulnerability to runoff and excessive loading of nutrients and sediments, and reduces dissolved oxygen concentration (OMETTO et al., 2004). These impacts reduce the spectrum of conditions that most of the taxa are able to live within (RESH et al., 1988), reducing taxa richness to a few tolerant and generalist groups (COUCEIRO et al., 2007) and produces shifts in abundance patterns (BRASIL et al., 2014).
Benthic macroinvertebrates have been recognized as indicators of water quality because there is substantial variation in taxa response to a gradient of environmental conditions within the group (e.g. ARMITAGE et al., 1983). Sensitive groups such as EPT are usually prevalent in habitats with better environmental quality, as most EPT species are sensitive to water pollution (e.g. DOLÉDEC et al., 2006; BACEY; SPURLOCK, 2007; HEPP; SANTOS, 2009). In accordance with our hypothesis, we found a prevalence of Ephemeroptera and Plecoptera in rural streams. The high richness of EPT is related to the availability of habitats, which may be the situation experienced by rural streams less affected by anthropogenic impacts (MCDONNEL et al., 1997). The low percentage of EPT in some of the urban streams (e.g. Lagoinha and Buritizinho) indicates that these places are disturbed as EPT tend to decrease or even disappear in areas where sources of urban pollution are present (HEPP et al., 2010). In addition, there was a high dominance of Oligochaeta in some urban streams such as Buritizinho and Lagoinha, which are assigned poor water quality (LENAT; CRAWFORD, 1994). Oligochaeta is well adapted to these environments, since they feed on organic matter and can tolerate hypoxic conditions (GIERE et al., 1999; GUIMARÃES-SOUTO et al., 2009).

Some Chironomidae families are usually associated with impacted environments due to their capacity to tolerate very low levels of oxygen (NESSIMIAN, 1995; CALLISTO et al., 2001) and their rapid growth rate (JACOBSEN; ENCALADA, 1998). Thus, we expected a comparatively higher prevalence of Chironomidae in more impacted urban streams than rural ones. Contrary to our 
expectations, chironomids were ubiquitous in both urban and rural streams. This could be explained by their high abundance and diversity in almost every freshwater habitat, comprising species with numerous ecological niches and also differing in their behaviors, habitat use and feeding preferences (CALLISTO et al., 2001). In a comparative analysis of fine versus coarse taxonomic resolution in chironomid responses to environmental predictors, GREFFARD et al. (2011) showed that there was substantial variation in ecological response even among finely resolved taxa, suggesting a loss of ecological information in coarser taxonomic analysis such as family resolution, as used in our study. As different chironomid species vary in their sensitivities to environmental stressors, they may be more useful at finer taxonomic resolution, such as genera or species (CAREW et al., 2007).

However, the choice of taxonomic resolution for biomonitoring involves a compromise between the difficulty of identifying organisms at higher taxonomic resolutions and the loss of information at lower resolutions (MARSHALL et al., 2006). With the exception of Chironomidae, our overall results suggest that identification to the coarse taxonomic level is acceptable in bioassessment protocols (ARSCOTT et al., 2006; CHESSMAN et al., 2007). Even at the family level, it was possible to detect significant differences among rural and urban stream macroinvertebrate assemblages. This is in accordance with previous studies that have shown that the use of family level is sufficient in clarifying differences in streams exposed to different impact levels or distinct environmental conditions (BOWMAN; BAILEY, 1998; WAITE et al., 2004; MELO, 2005; HEINO; SOININEN, 2007).

Biodiversity indexes, such as richness and abundance, are influenced by environmental and biotic factors (BISPO et al., 2006). The present study showed differences in these indexes, presumably due to differences in habitat conditions caused by changes in land use. The highest taxonomic richness (see Appendix) was found in rural streams, possibly due to the presence of native riparian vegetation providing higher habitat heterogeneity (HEPP et al., 2010) and allochthonous matter input (LANGHANS et al., 2006). Otherwise, urbanization frequently causes changes in the water quality due to the removal of marginal vegetation, which allows an input increment of sediment, nutrients and pollutants (NESSIMIAN et al., 2008). As a consequence, intolerant taxa suffer extinction, leading to richness decreases and abundance increase of tolerant taxa (SMITH; LAMP 2008).
The estimation of biodiversity indexes relying on coarse taxonomic levels is problematic, especially for Shannon-Wiener (WU, 1982). The less precise the identification, the lower the diversity index values (JONES, 2008). Although high taxonomic resolution is desirable for biodiversity estimates, the ability to identify macroinvertebrate organisms from the Uberabinha river catchment to a lower taxonomic level than family would be very time consuming due to the required sampling effort. Furthermore, some studies have shown a strong correlation between species richness and richness based on both genus and family levels among macroinvertebrates (FURSE et al., 1984; HEWLETT, 2000; GUEROLD, 2000; MARSHALL et al., 2006). In a study about taxonomic resolution of freshwater macroinvertebrate samples from an Australian dryland catchment, Marshall et al. (2006) showed that identification to family level is highly correlated to species level identification $(>0.90 \%)$, suggesting that estimates of richness based on family resolution may adequately reflect species richness. Thus, we assume that some level of information was lost due to sample identification to family level. However, considering our results and previous studies, we believe that the taxonomic resolution chosen was sufficient for comparison purposes between rural and urban streams.

In this study, community composition and abundance were significantly different between rural and urban streams, reflecting different ecological conditions related to land use. In addition, there is a convergence of the bioindicatorbased approach (BMWP), the habitat-based approach (RAP) and the biodiversity metrics (H', J', $\%$ EPT), showing that rural streams are higher quality habitats than urban streams in the Uberabinha river catchment. Also, the high density of Oligochaeta in some urban streams may be evidence of organic enrichment (SCHENKOVÁ; HELEŠIC 2006) possibly caused by waste disposal. In spite of regular water and sewage provisions servicing the urban zone of Uberlândia municipality, our results show a disturbing picture regarding the environmental quality of Uberlândia's urban streams. Therefore, we strongly encourage stakeholders (politicians, local scientists, engineers and water users) to partake in joint discussions to rethink management actions for the urban part as well the whole of the Uberabinha river catchment.

\section{ACKNOWLEDGEMENTS}

We thank Masterson Ferreira, Cairo Divino and Geraldo S. Oliveira from DMAE (Uberlândia's 
Water and Sewerage Department) for logistic support. We also thank CNPq and FAPEMIG (Proc. CRA - APQ-02033-10) for financial support. We are grateful to Dr. Adriano Sanches Melo for an early review of the manuscript.

RESUMO: Atividades agrícolas, como pecuária e cultivo de lavouras, podem levar a degradação dos ambientes aquáticos vizinhos, provocando erosão do solo e o carreamento de sedimentos finos, nutrientes (por exemplo, nitrogênio, fósforo, potássio) e pesticidas para os leitos dos rios. A urbanização também é responsável por uma variedade de impactos nos sistemas fluviais, incluindo a poluição por metais pesados, óleos, esgoto doméstico e lixo. Neste estudo, nós avaliamos o impacto do uso da terra na saúde da bacia hidrográfica do rio Uberabinha, utilizando macroinvertebrados bentônicos como bioindicadores da qualidade da água. Em geral, os córregos rurais apresentaram melhores condições ecológicas do que os córregos urbanos. Tanto a composição de espécies como a abundância da comunidade bentônica mostraram diferenças significativas entre os dois grupos. Os córregos urbanos apresentaram uma maior dominância de Oligochaeta, Hirudinea e Gastropoda, organismos indicadores de baixa qualidade ambiental. Os córregos rurais apresentaram maior riqueza e diversidade de grupos taxonômicos, tais como Ephemeroptera, Plecoptera, Trichoptera, Odonata e Hemiptera. Nossas análises mostraram congruência (alta correlação) entre os índices tradicionais de diversidade (índice de ShannonWiener - H ', equitabilidade de Pielou - J) e as métricas de biomonitoramento (\% Ephemeroptera, Plecoptera e Trichoptera - EPT, Biological Monitoring Work Party - BMWP , índice baseado na composição taxonômica das comunidades e Rapid Assessment Protocol - RAP, abordagem baseada em características físicas do habitat). Cinco dos sete córregos rurais analisados apresentaram boa qualidade da água, de acordo com BMWP e RAP. Nenhum dos córregos urbanos apresentaram boa qualidade ambiental. Nossos resultados mostraram que córregos urbanos do município de Uberlândia possuem má qualidade ambiental. Nós encorajamos que o programa de recomposição manejo das matas ciliares dos córregos rurais do rio Uberabinha seja estendido aos córregos urbanos do município.

PALAVRAS-CHAVE: Degradação aquática. Diversidade de espécies. EPT. BMWP.

\section{REFERENCES}

ALBA-TERCEDOR, J. Macroinvertebrados acuaticos y calidad de las aguas de los rios. In: SIMPOSIO DEL AGUA EN ANDALUCIA (SIAGA), 4., Almeria. Anais..., 1996, p. 203-213.

ALLAN, J. D.; ERICKSON, D. L.; FAY, J. The influence of catchment land use on stream integrity across multiple spatial scales. Freshwater Biology, v. 37, p. 149-61, 1997. https://doi.org/10.1046/j.1365-

2427.1997.d01-546.x

ANA, 2015. Programa Produtor de Água. Available on line at:

http://produtordeagua.ana.gov.br/Portals/0/DocsDNN6/Seminario_Marco_2015/Apresenta\%C3\%A7\%C3\%A3 o\%20Buriti\%20ANA\%202015.pdf. [Acessed: 09/03/2017]

ANDERSON, M. J. A new method for non-parametric multivariate analysis of variance. Austral Ecology, v. 26, p. 32-46, 2001. https://doi.org/10.1046/j.1442-9993.2001.01070.x

https://doi.org/10.1111/j.1442-9993.2001.01070.pp.x

ARMITAGE, P. D.; MOSS, D.; WRIGHT, J. F.; FURSE, M. T. The performance of a new biological water quality score system based on macroinvertebrates over a wide range of unpolluted running-water sites. Water Research, v. 17, p. 333-347, 1983. https://doi.org/10.1016/0043-1354(83)90188-4

ARSCOTT, D. B.; JACKSON, J. K.; KRATZER, E. B. Role of rarity and taxonomic resolution in a regional and spatial analysis of stream macroinvertebrates. Journal of North American Benthological Society, v. 25, p. 977-997, 2006. https://doi.org/10.1899/0887-3593(2006)025[0977:RORATR]2.0.CO;2

BACEY, J.; SPURLOCK, F. (2007) Biological assessment of urban and agricultural streams in the California Central Valley. Environmental Monitoring Assessment, v. 130, p. 483-493, 2007.

https://doi.org/10.1007/s10661-006-9438-8 
BISPO, P. C.; OLIVEIRA, L. G.; BINI, L. M.; SOUZA, K. G. Ephemeroptera, Plecoptera and Trichoptera assemblages from riffles in mountain streams of Central Brazil: environmental factors influencing the distribution and abundance of immatures. Brazilian Journal of Biology, v. 66, p. 611-622, 2006. https://doi.org/10.1590/S1519-69842006000400005

BORGES, D. J. V. \& CUNHA, A. M. O.; MARÇAL-JÚNIOR, O. As condições sócio-ambientais de áreas de preservação permanente na zona urbana de Uberlândia: Aspectos paisagísticos e sociais. Caminhos de geografia, v. 7, n. 18, p. 146-161.

BOWMAN, M. F ., BAILEY, R. C. Does taxonomic resolution affect the multivariate description of the structure of freshwater benthic macroinvertebrate communities? Cannadian Journal of Fisheries and Aquatic Sciences, v. 54, p. 1802-1807, 1998. https://doi.org/10.1139/f97-085

BRANDÃO, S. L.; LIMA, S. C. Diagnóstico ambiental das Áreas de Preservação Permanente (APP), margem esquerda do rio Uberabinha, em Uberlândia (MG). Caminhos de Geografia, v. 3, n. 7, p. 41-62, 2002.

BRASIL, L. S.; JUEN, L.; CABETTE, H. S. R. The effects of environmental integrity on the diversity of mayflies, Leptophlebiidae (Ephemeroptera), in tropical streams of the Brazilian Cerrado. Annales de Limnologie - International Journal of Limnology, v. 50, p. 325-334, 2014. https://doi.org/10.1051/limn/2014026

BUSS, D. F.; BAPTISTA, D. F.; SILVEIRA, M. P.; NESSIMIAN, J. L.; DORVILLÉ, L. F. M. (2002) Influence of water chemistry and environmental degradation on macroinvertebrate assemblages in a river basin in south-east Brazil. Hydrobiologia, v. 481, p. 125-136, 2002. https://doi.org/10.1023/A:1021281508709

CALLISTO, M.; MARQUES, M.M.; BARBOSA, F.A.R. Deformities in larval Chironomus (Diptera, Chironomidae) from the Piracicaba river, southeast Brazil. Verhandlungen des Internationalen Verein Limnologie, v. 27, p. 2699-2702, 2000.

CALLISTO, M.; MORETTI, M.; GOULART, M.D.C. (2001) Macroinvertebrados bentônicos como ferramenta para avaliar a saúde de riachos. Revista Brasileira de Recursos Hídricos, v. 6, p. 71-82, 2001. https://doi.org/10.21168/rbrh.v6n1.p71-82

CALliSTO, M.; FERREIRA, W.; MORENO, P.; GOULART, M.D.C.; PETRUCIO, M. Aplicação de um protocolo de avaliação rápida da diversidade de habitats em atividades de ensino e pesquisa (MG-RJ). Acta Limnologica Brasiliensia, v. 13, p. 91-98, 2002.

CAREW, M. E.; PETTIGROVE, V.; COX, R. L.; HOFFMANN, A. A. The response of Chironomidae to sediment pollution and other environmental characteristics in urban wetlands. Freshwater Biology, v. 52, p. 2444 - 2462, 2007. https://doi.org/10.1111/j.1365-2427.2007.01840.x

CHESSMAN, B.; WILLIAMS, S.; BESLEY, C. Bioassessment of streams with macroinvertebrates: effect of sample habitat and taxonomic resolution. Journal of North American Benthological Society, v. 26, p. 546565, 2007. https://doi.org/10.1899/06-074.1

COUCEIRO, S. R.; HAMADA, N.; LUZ, S. L.; FORSBERG, B.R.; PIMENTEL, T. P. Deforestation and sewage effects on aquatic macroinvertebrates in urban streams in Manaus, Amazonas, Brazil. Hydrobiologia, v. 575, p. 271-284, 2007. https://doi.org/10.1007/s10750-006-0373-z

COUCEIRO, S. R. M.; HAMADA, N.; FORSBERG, B. R.; PIMENTEL, T. P.; LUZ S. L. B., 2012. A macroinvertebrate multimetric index to evaluate the biological condition of streams in the Central Amazon region of Brazil. Ecological Indicators, v. 18, p. 118-125, 2012. https://doi.org/10.1016/j.ecolind.2011.11.001 
DOLÉDEC, S.; PHILLIPS, N.; SCARSBROOK, M.; RILEY, R. H.; TOWSEND, C. R. Comparison of structural and functional approaches to determining landuse effects on grassland stream invertebrate communities. Journal of North American Benthological Society, v. 25, p. 44-60, 2006. https://doi.org/10.1899/0887-3593(2006)25[44:COSAFA]2.0.CO;2

EPA (Environmental Protection Agency). Biological criteria for the protection of aquatic life. Division of water quality monitoring and assessment. Columbus, v.1-3, 1987, 120p.

FURSE, M. T.; MOSS, D.; WRIGHT, J. F.; ARMITAGE, P. D. The influence of seasonal and taxonomic factors on the ordination and classification of running-water sites in great britain and on the prediction of their macro-invertebrate communities. Freshwater biology, v. 14, n. 3, p. 257-280, 1984.

https://doi.org/10.1111/j.1365-2427.1984.tb00040.x

GIERE, O.; PREUSSE, J. H.; DUBILIER, N. Tubificoides benedii (Tubificidae, Oligochaeta) - a pioneer in hypoxic and sulfidic environments: An overview of adaptive pathways. Hydrobiologia, v. 406, p. 235-241, 1999. https://doi.org/10.1023/A:1003711914788

GODRON, M.; FORMAN, R. T. T. Landscape modification and changing ecological characteristics. In: MOONEY, H. A.; GODRON, M. (eds) Disturbance and ecosystems, components and response. New York: SpringerVerlag, 1983, 12-28. https://doi.org/10.1007/978-3-642-69137-9_2

GREFFARD, M. H.; SAULNIER-TALBOT, E.; GREGORY-EAVES, I. A comparative analysis of fine versus coarse taxonomic resolution in benthic chironomid community analyses. Ecological Indicators, v. 11, P. 15411551, 2011. https://doi.org/10.1016/j.ecolind.2011.03.024

GUEROLD, F. Influence of taxonomic determination level on several community indices. Water Research, v. 34, n. 2, p. 487-492, 2000. https://doi.org/10.1016/S0043-1354(99)00165-7

GUIMARÃES, R. M.; FACURE, K. G.; PAVANIN, L. A.; JACOBUCCI, G. B. Water quality characterization of urban streams using benthic macroinvertebrate community metrics. Acta Limnologica Brasiliensia, v. 21, p. 217-226, 2009.

GUIMARÃES-SOUTO, R. M. FACURE, K. G.; PAVANIN, L. A.; JACOBUCCI, G. B. Influence of environmental factors on benthic macroinvertebrate communities of urban streams in Vereda habitats, Central Brazil. Acta Limnologica Brasiliensia, v. 23, n. 3, p. 293-306, 2011. https://doi.org/10.1590/S2179975X2012005000008

GUTIÉRREZ-FONSECA, P. E.; LORION, C. M. Application of the BMWP-Costa Rica biotic index in aquatic biomonitoring: sensitivity to collection method and sampling intensity. Revista de Biología Tropical, v. 62, p. 275-289, 2014. https://doi.org/10.15517/rbt.v62i0.15792

HANNAFORD, M. J.; BARBOUR, M. T.; RESH, V. H. Training reduces observer variability in visual-based assessments of stream habitat. Journal of North American Benthological Society, v. 16, p. 853-860, 1997. https://doi.org/10.2307/1468176

HEINO, J.; SOININEN, J. Are higher taxa adequate surrogates for species-level assemblage patterns and species richness in stream organisms? Biological Conservation, v. 137, 2007.

HEPP, L. U.; MILESI, S. V.; BIASI, C.; RESTELLO, R. M. Effects of agricultural and urban impacts on macroinvertebrates assemblages in streams (Rio Grande do Sul, Brazil). Zoologia, v. 27, p. 106-113, 2010. https://doi.org/10.1590/S1984-46702010000100016

HEPP. L. U.; SANTOS, S. (2009) Benthic communities of streams related to different land uses in a hydrographic basin in southern Brazil. Environmental Monitoring and Assessment, v. 157, p. 305-318, 2009. https://doi.org/10.1007/s10661-008-0536-7 
HEWLETT, R. Implications of taxonomic resolution and sample habitat for stream classification at a broad geographic scale. Journal of the North American Benthological Society, v. 19, n. 2, p. 352-361, 2000. https://doi.org/10.2307/1468077

IBGE, 2010. Censo 2010. Fundação Instituto Brasileiro de Geografia e Estatística, dados referentes ao município de Uberlândia. Available on line at: <http://www.ibge.gov.br>. [Acessed: 17/01/2016]

JACOBSEN, D.; ENCALADA, A. The macroinvertebrate fauna of Ecuadorian highland streams in the wet and dry season. Archiv fur Hydrobiologie, v. 142, p. 53-70, 1998. https://doi.org/10.1127/archivhydrobiol/142/1998/53

JONES, F. C. Taxonomic sufficiency: the influence of taxonomic resolution on freshwater bioassessments using benthic macroinvertebrates. Environmental Reviews, v. 16, p. 45-69, 2008. https://doi.org/10.1139/A07-010

JUNQUEIRA, V. M.; CAMPOS, S. C. M. Adaptation of the "BMWP" method for water quality evaluation to Rio das Velhas watershed (Minas Gerais, Brazil). Acta Limnologica Brasiliensia, v. 10, p. 125-135, 1998.

LANGHANS, S. D.; RICHARD, U.; RUEEGG, J.; UEHLINGER, U.; EDWARDS, P.; DOERING, M.; TOCKNER, K. Environmental heterogeneity controls organic-matter dynamics in river-floodplain ecosystems. Polish Journal of Ecology, v. 54, p. 675-680, 2006.

LENAT, D. R.; CRAWFORD, J. K. Effects of land use on water quality and aquatic biota of three North Carolina piedmont streams. Hydrobiologia, v. 294, p. 185-199, 1994. https://doi.org/10.1007/BF00021291

LENAT, D. R.; RESH, V. H. Taxonomy and stream ecology - The benefits of genus- and species-level identification. Journal of North American Benthological Society, v. 20, n. 2, p. 287-298. https://doi.org/10.2307/1468323

MANGADZE, T.; BERE, T.; MWEDZI, T. Choice of biota in stream assessment and monitoring programs intropical streams: A comparison of diatoms, macroinvertebrates and fish. Ecological Indicators, v. 63, p. 128143, 2016. https://doi.org/10.1016/j.ecolind.2015.11.029

MARSHALL, J. C.; STEWARD, A. L.; BRONWYN, D. H. Taxonomic resolution and quantification of freshwater macroinvertebrate samples from an Australian dryland river: the benefits and costs of using species abundance data. Hydrobiologia, v. 572, p. 171-194. https://doi.org/10.1007/s10750-005-9007-0

MASON, C. F. Biology of Freshwater Pollution. 4th ed. New York: Prentice Hall, 2002.

MCDONNELL, M. J.; PICKETT, S. T. A.; GROFFMAN, P.; BOHLEN, P.; POUYAT, R. V.; ZIPPERER, W. C.; PARMELEE, R. W.; CARREIRO, M. M.; MEDLEY, K. Ecosystem processes along an urban-to-rural gradient. Urban Ecosystems, v. 1, p. 21-36, 1997. https://doi.org/10.1023/A:1018598708346 https://doi.org/10.1023/A:1018527611980 https://doi.org/10.1023/A:1014359024275

MELO, A. S. Effects of taxonomic and numeric resolution on the ability to detect ecological patterns at a local scale using stream macroinvertebrates. Archiv fur Hydrobiologie, v. 164, 309-323, 2005. https://doi.org/10.1127/0003-9136/2005/0164-0309

MELO, A. S.; HEPP, L. U. Ferramentas estatísticas para análise de dados provenientes de biomonitoramento. Oecologia Brasiliensis, v. 12, p. 463-486, 2008. https://doi.org/10.4257/oeco.2008.1203.07

MERRIT, R. W.; CUMMINS, K. W. An introduction to the aquatic insects of North America. Dubuque: Kendal/Hunt Publishes, 1984, 862 p. 
MILESI, S. V.; BIASI, C.; RESTELLO, R. M.; HEPP, L. U. Distribution of benthic macroinvertebrates in Subtropical streams (Rio Grande do Sul, Brazil). Acta Limnologica Brasiliensia, v. 21, p. 419-429, 2009.

MOORE, A. A.; PALMER, M. A. Invertebrate biodiversity in agricultural and urban headwater streams: implications for conservation and management. Ecological. Applications, v. 15, p. 1169-1177, 2005. https://doi.org/10.1890/04-1484

NESSIMIAN, J. L. Abundância e biomassa de macroinvertebrados de um brejo de dunas no litoral do Estado do Rio de Janeiro. Revista Brasileira de Biologia, v. 55, p. 661-683, 1995.

NESSIMIAN, J. L.; VENTICINQUE, E. M.; ZUANON, J.; DE MARCO, P.; GORDO, M.; FIDELIS, L.; BATISTA, J. D.; JUEN, L. Land use, habitat integrity, and aquatic insect assemblages in Central Amazonian streams. Hydrobiologia, v. 614, p. 117-131, 2008. https://doi.org/10.1007/s10750-008-9441-x

NISHIYAMA, L. Geologia do município de Uberlândia e áreas adjacentes. Sociedade e Natureza,v. 1, n. 1, p. 9-16, 1989.

OMETTO, J. P.; GESSNER, A.; MARTINELLI, L. A.; BERNARDES, M. C. Macroinvertebrate community as indicator of land-use changes in tropical watersheds, southern Brazil. Ecohydrology \& Hydrobiology, v. 4, n. 1, p. 37-49, 2004.

PEDERSEN, E. R.; PERKINS, M. A. The Use of Benthic Invertebrate Data for Evaluating Impacts of Urban Runoff. Hydrobiologia, v. 139, p. 13-22, 1986. https://doi.org/10.1007/BF00770238

R DEVELOPMENT CORE TEAM. R: A language and environment for statistical computing. R Foundation for Statistical Computing. Vienna, Austria, 2011.

RESH, V. H.; JACKSON, J. K. Rapid assessment approaches to biomonitoring using benthic macroinvertebrates. In: Chapman and Hall, 1993. p. 195-223. Freshwater biomonitoring and benthic macroinvertebrates, New York:

RESH, V. H.; MYERS, M. J.; HANNAFORD, M. Macroinvertebrates as biotic indicators of environmental quality. In: HAUER, F.R.; LAMBERTI, G.A. Methods in Stream Ecology. San Diego: Academic Press, 1996. p. 647-667.

RESH, V. H.; BROWN, A.; COVICH, A. P.; GURTZ, M. E., LI, H. W.; MINSHALL, W.; REICE, S.; SHELDON, A. L.; WALLACE, J.B.; WISSMAR, R. The role of disturbance theory in stream ecology. Journal of North American Benthological Society, v. 7, p. 433-455, 1988. https://doi.org/10.2307/1467300

ROLDÁN-PÉREZ, G. A. Bioindicación de la Calidad del Agua en Colombia: Uso del Método BMWP/Col. Medellín: Imprenta Universidad de Antioquia, 2003.

ROSA, R.; LIMA, S. C. C.; ASSUNÇÃO, W. L. Abordagem preliminar das condições climáticas de Uberlândia (MG). Sociedade e Natureza, v. 3, n. 5, p. 91-108, 1991.

ROSENBERG, D. M.; RESH, V. H. Introduction to freshwater biomonitoring and benthic macroinvertebrates. In:__ Freshwater Biomonitoring and Benthic Macroinvertebrates. New York: Chapman Hall, p. 1-9, 1993.

SCHENKOVÁ, J.; HELEŠIC, J. Habitat preferences of aquatic Oligochaeta (Annelida) in the Rokttná River, Czech Republic - a small highland stream. Hydrobiologia, v. 564, p. 117-126, 2006.

https://doi.org/10.1007/s10750-005-1713-0 
SMITH, R. F.; LAMP, W. O. 2008. Comparison of insect communities between adjacent headwater and mainstem streams in urban and rural watersheds. Journal of North American Benthological Society, n. 27, n. 1, p. 161-175.

STEPENUCK, K. F.;CRUNKILTON, R. L.; WANG, L. Impacts of urban landuse on macroinvertebrate communities in southeastern Wisconsin streams. Journal WPCF, v. 38, p. 1041-1051, 2002.

https://doi.org/10.1111/j.1752-1688.2002.tb05544.x

WAITE, I. R.; HERLIHY, A. T.; LARSEN, D. P.; URQHUART, N. S.; KLEMM, D. J. The effects of macroinvertebrate taxonomic resolution in large landscape bioassessments: an example from the Mid-Atlantic Highlands, USA. Freshwater Biology, v. 49, p. 474-489, 2004. https://doi.org/10.1111/j.1365-

2427.2004.01197.x

WALSH, C. J.; SHARPE, A. K.; BREEN, P. F.; SONNEMAN, J. A. Effects of urbanization on streams of the Melbourne region, Victoria, Australia. I. Benthic macroinvertebrate communities. Freshwater Biology, v. 46, p. 535-551, 2001. https://doi.org/10.1046/j.1365-2427.2001.00690.x

WYŻGA, B.; OGLĘCKI, P.; HAJDUKIEWICZ, H.; ZAWIEJSKA, J.; RADECKI-PAWLIK, J.; SKALSKI, T.; MIKUŚ, P. Interpretation of the invertebrate-based BMWP-PL index in a gravel-bed river: insight from the Polish Carpathians. Hydrobiologia 712: 71-88, 2013. https://doi.org/10.1007/s10750-012-1280-0

ZAMORA-MUÑOZ, C.; SÁINZ-CANTERO, C. E.; SÁNCHEZ-ORTEGA, A.; ALBA-TERCEDOR, J. Are biological indices BMWP' and ASPT' and their significance regarding water quality seasonally dependent? Factors explaining their variations. Water Research, v. 29, p. 285-290, 1995. https://doi.org/10.1016/00431354(94)E0125-P 
Appendix

Table 1. Taxonomic composition and abundance, richness, Shannon-Wiener diversity (H') and Pielou's evenness (J') indexes of the surveyed streams. Seven rural streams are presented at the left side of the table. The urban streams are presented on the right side of the table (grey). BjFl - Beija-Flor stream; Ranch Rancharia stream; BJd - Bom-Jardim stream; Laged - Cabeceira do Lageado stream; Mach - Machados stream; Gord - Gordura stream; Pedr - Rio das Pedras stream; Liso - Liso stream; Oleo - Óleo stream; Lago - Lagoinha stream; Buri - Buritizinho stream; Fund - Fundo stream. Abundance was calculated as the average number of individuals at the three substrate samples.

\begin{tabular}{|c|c|c|c|c|c|c|c|c|c|c|c|c|}
\hline & \multicolumn{7}{|c|}{ Rural streams } & \multicolumn{5}{|c|}{ Urban streams } \\
\hline & $\mathrm{BjFl}$ & Ranch & $\mathrm{BJd}$ & Laged & Mach & Gord & Pedr & Liso & Oleo & Lago & Buri & Fund \\
\hline \multicolumn{13}{|l|}{ Diptera } \\
\hline Chironomidae & 368 & 312 & 146.33 & 108.67 & 20.66 & 76.33 & 545.67 & 292 & 1142.7 & 2661.3 & 4000.3 & 44.66 \\
\hline Simuliidae & 1560 & 125.66 & 20.33 & 0 & 18 & 0.66 & 20.33 & 159.66 & 33.66 & 84.33 & 4.33 & 9.66 \\
\hline Ceratopogonidae & 1 & 7.33 & 4 & 0.33 & 0 & 0 & 3 & 1.66 & 2 & 0.33 & 0 & 0.33 \\
\hline Tipulidae & 2.33 & 4 & 1.33 & 1.66 & 2 & 0 & 2.66 & 0.33 & 0.33 & 0 & 0.33 & 0 \\
\hline Empididae & 0.33 & 1.66 & 0 & 0 & 0 & 0 & 2.66 & 7 & 54 & 0.33 & 0 & 0 \\
\hline Tabanidae & 0 & 1 & 0 & 0 & 0 & 0 & 0 & 0 & 0 & 0 & 0 & 0 \\
\hline Sciomyzidae & 0 & 0 & 0 & 0 & 0 & 0 & 0 & 0 & 0 & 0.33 & 0 & 0 \\
\hline Culicidae & 0 & 0 & 0 & 0 & 0 & 0 & 0 & 0.33 & 0 & 0 & 0 & 0 \\
\hline Stratiomidae & 0 & 0 & 0 & 0 & 0 & 0 & 0 & 0.33 & 0 & 0 & 0 & 0 \\
\hline \multicolumn{13}{|l|}{ Hemiptera } \\
\hline Naucoridae & 0.66 & 0.33 & 19.33 & 0 & 1.66 & 0 & 0.33 & 0 & 0 & 0 & 0 & 0 \\
\hline Helotrephidae & 0.33 & 1 & 0.33 & 0.33 & 0 & 0 & 0 & 0 & 0 & 0 & 0 & 0 \\
\hline Veliidae & 0 & 0 & 0 & 0 & 0.33 & 0 & 0 & 0 & 0 & 0.66 & 0 & 0 \\
\hline Gerridae & 0 & 0.33 & 0 & 0 & 0 & 0 & 0 & 0 & 0 & 0 & 0 & 0 \\
\hline Belostomatidae & 2 & 0 & 0 & 2 & 0 & 0 & 0 & 0 & 0 & 0 & 0 & 0 \\
\hline Pleidae & 0 & 0 & 0 & 1 & 0 & 0 & 0 & 0 & 0 & 0 & 0 & 0 \\
\hline \multicolumn{13}{|l|}{ Coleoptera } \\
\hline Elmidae & 15 & 19.66 & 88 & 30 & 4 & 0.33 & 34.33 & 0 & 0.33 & 0 & 0 & 73.66 \\
\hline Psephenidae & 0 & 0 & 0 & 0 & 0 & 0 & 0.66 & 0 & 0 & 0 & 0 & 0 \\
\hline Nototeridae & 0 & 0 & 0.33 & 0 & 0 & 0 & 0 & 0 & 0 & 0 & 0 & 0 \\
\hline
\end{tabular}




\begin{tabular}{|c|c|c|c|c|c|c|c|c|c|c|c|c|}
\hline Hydrophilidae & 0 & 0.33 & 0 & 0 & 0.66 & 0.33 & 0 & 15 & 1 & 0.33 & 0.33 & 0 \\
\hline \multicolumn{13}{|l|}{ Trichoptera } \\
\hline Hydropsychidae & 3.33 & 3.33 & 6.33 & 32.66 & 5.33 & 0 & 36 & 0.33 & 127.67 & 0.33 & 0 & 16 \\
\hline Hydroptilidae & 3.33 & 2.33 & 10.66 & 3 & 0 & 0.66 & 20 & 0.66 & 5 & 0 & 0 & 0.66 \\
\hline Polycentropodidae & 1.66 & 1.33 & 2 & 2 & 0 & 0 & 0.33 & 0 & 2.66 & 0 & 0 & 0.33 \\
\hline Limnephilidae & 0 & 1 & 0 & 0.66 & 0 & 0 & 0 & 0 & 0 & 0 & 0 & 0 \\
\hline Xiphocentronidae & 0 & 0 & 0 & 0 & 0 & 0 & 1 & 0 & 0 & 0 & 0 & 0 \\
\hline Glossosomatidae & 0 & 0 & 0.66 & 0 & 0 & 0 & 0 & 0 & 0 & 0 & 0 & 0 \\
\hline Leptoceridae & 0 & 0 & 0.66 & 0 & 0 & 0 & 0 & 0 & 0 & 0 & 0 & 0 \\
\hline Anomalopsychidae & 8.66 & 0 & 0 & 1 & 0.66 & 0 & 0 & 0 & 0 & 0 & 0 & 0 \\
\hline Philopotamidae & 0 & 0 & 0 & 0.33 & 3 & 0 & 0.33 & 0 & 0 & 0 & 0 & 0 \\
\hline Hydrobiosidae & 0 & 0 & 0 & 1 & 0 & 0 & 0 & 0 & 0 & 0 & 0 & 0 \\
\hline Sericostomatidae & 0 & 0 & 0 & 0.66 & 0 & 0 & 0 & 0 & 0 & 0 & 0 & 0 \\
\hline Odontoceridae & 0 & 0 & 0 & 0.33 & 0.33 & 0 & 0 & 0 & 0 & 0 & 0 & 0 \\
\hline \multicolumn{13}{|l|}{ Ephemeroptera } \\
\hline Baetidae & 464.33 & 19.66 & 23.33 & 2.66 & 44.33 & 1.66 & 72 & 0 & 0 & 0.66 & 0 & 1.33 \\
\hline Leptophlebiidae & 49 & 3.66 & 33.33 & 3.33 & 0 & 0 & 28 & 0 & 0 & 0 & 0 & 1 \\
\hline Leptohyphidae & 98.33 & 2.66 & 5.66 & 2.66 & 0 & 0 & 10.33 & 0 & 0 & 0 & 0 & 0.66 \\
\hline Euthyplocidae & 0 & 0.66 & 0 & 1.33 & 0 & 0 & 1.66 & 0 & 0 & 0 & 0 & 0.33 \\
\hline Ephemeridae & 0 & 0 & 0.66 & 0 & 0 & 0 & 0 & 0 & 0 & 0 & 0 & 0 \\
\hline \multicolumn{13}{|l|}{ Plecoptera } \\
\hline Perlidae & 42.66 & 1.66 & 0.33 & 0.66 & 1.66 & 0 & 1.33 & 0 & 0 & 0 & 0 & 11.33 \\
\hline \multicolumn{13}{|l|}{ Odonata } \\
\hline Coenagrionidae & 0 & 4.33 & 0 & 0.66 & 0 & 0 & 0 & 0 & 0 & 0 & 0 & 0 \\
\hline Calopterygidae & 0 & 0.66 & 0.66 & 0.66 & 0 & 0 & 0 & 0 & 0 & 0 & 0 & 0.33 \\
\hline Libellulidae & 2 & 1 & 0.66 & 0.66 & 0.66 & 0 & 0 & 0 & 0.33 & 0 & 0 & 1.66 \\
\hline Gomphidae & 0 & 1.33 & 0.33 & 0 & 0.33 & 0.66 & 0 & 0 & 0 & 0 & 0 & 0 \\
\hline Corduliidae & 5 & 0 & 1.66 & 0.33 & 1 & 2.66 & 2 & 0 & 0.66 & 0 & 0 & 0 \\
\hline
\end{tabular}




\begin{tabular}{|c|c|c|c|c|c|c|c|c|c|c|c|c|}
\hline \multicolumn{13}{|l|}{ Lepidoptera } \\
\hline Pyralidae & 1 & 0 & 0 & 1.66 & 0 & 0 & 7.66 & 0 & 0 & 0 & 0 & 0 \\
\hline Collembola & 0 & 0 & 0 & 0.33 & 0 & 0 & 0 & 0 & 0 & 0.66 & 0 & 0 \\
\hline \multicolumn{13}{|l|}{ Anellida } \\
\hline Oligochaeta & 42.33 & 39 & 66 & 1.33 & 10 & 16.33 & 4 & 420.66 & 313 & 4139.7 & 45238 & 1.66 \\
\hline Hirudinea & 1.33 & 0 & 2.33 & 0 & 0 & 1.66 & 0 & 8.66 & 45 & 0.33 & 20.66 & 0 \\
\hline \multicolumn{13}{|c|}{ Platyhelminthes } \\
\hline Planaridae & 0 & 0 & 0 & 0 & 0 & 3 & 0 & 0 & 0 & 0 & 0 & 0 \\
\hline \multicolumn{13}{|l|}{ Gastropoda } \\
\hline Planorbidae & 0 & 0 & 0 & 0 & 0 & 34.66 & 0 & 3 & 34 & 0 & 6 & 0 \\
\hline Lymnaeidae & 0 & 0 & 0 & 0 & 0 & 3 & 0 & 64 & 21 & 0 & 1.33 & 0 \\
\hline Hydrobiidae & 0 & 0 & 0 & 0 & 0 & 0 & 0 & 0 & 0.33 & 0 & 0 & 0 \\
\hline Richness & 21 & 25 & 24 & 28 & 17 & 13 & 21 & 14 & 17 & 12 & 8 & 15 \\
\hline $\mathbf{H}^{\prime}$ & 1.25 & 1.42 & 1.74 & 1.5 & 2.41 & 1.4 & 1.36 & 1.03 & 1.01 & 0.72 & 0.28 & 1.43 \\
\hline J' & 0.43 & 0.49 & 0.67 & 0.56 & 0.97 & 0.66 & 0.5 & 0.45 & 0.48 & 0.4 & 0.16 & 0.62 \\
\hline
\end{tabular}

